\title{
Minerals and essential fatty acids of the exotic fruit Physalis peruviana $L$.
}

\author{
Minerais e ácidos graxos essenciais da fruta exótica Physalis peruviana L. \\ Eliseu RODRIGUES ${ }^{1}$, Ismael Ivan ROCKENBACH ${ }^{1 \star}$, Ciriele CATANEO ${ }^{1}$, \\ Luciano Valdemiro GONZAGA ${ }^{1}$, Eduardo Sidinei CHAVES $^{2}$, Roseane FETT ${ }^{1}$
}

\begin{abstract}
Physalis peruviana is an exotic fruit that belongs to the Solanaceae family and which has recently started to be produced in Brazil, mainly in the Southern region. Once there is few data regarding its chemical composition, this work presents the centesimal and mineral composition and the fatty acid profile of the lipidic fraction of Physalis peruviana. Concerning the centesimal composition, Physalis presented high contents of ashes and total lipids, 0.8 and $3.16 \mathrm{~g} .100 \mathrm{~g}^{-1}$, respectively. In its mineral composition, $\mathrm{K}, \mathrm{Mg}$, Ca and Fe were the main elements, and $\mathrm{Fe}$ is present in concentrations higher than those in the common sources such as beans. The lipidic fraction presented predominance of the linoleic acid $(72,42 \%)$ in its composition.

Keywords: physalis; chemical composition; fatty acids; minerals.
\end{abstract}

\section{Resumo}

Physalis peruviana é uma fruta exótica pertencente à família Solanaceae com produção recente no Brasil, principalmente na região Sul. Como há poucos dados em relação à sua composição química, este trabalho apresenta a composição centesimal e mineral e o perfil de ácidos graxos da fração lipídica da Physalis peruviana. Em relação à composição centesimal, a physalis apresentou alto conteúdo de cinzas e de lipídios totais, 0,8 e 3,16 g.100 g-1 , respectivamente. Em sua composição mineral, o K, Mg, Ca e Fe foram os principais elementos, estando o ferro presente em concentrações superiores em relação a fontes conhecidas como o feijão. A fração lipídica apresenta predominância de ácido linoleico $(72,42 \%)$ em sua composição.

Palavras-chave: physalis; composição química; ácidos graxos; minerais.

\section{Introduction}

High production of several native and exotic fruits in Brazil is due to its large territory and its presence in areas of tropical and temperate climates (GRANADA; ZAMBIAZI; MENDONÇA, 2004). However, national fruit production has a great expansion potential once several native and exotic fruits are not economically explored. Attempts to turn such unexplored cultures into reasonable ones are in course, mainly for atemóia, maná, canistel, mirtilo, lichia, physalis and star fruit (LAGO; GOMES; SILVA, 2006).

P. peruviana is an exotic fruit that belongs to the Solanaceae family and Physalis genus from Amazon and Andes. However, some varieties are cultivated in America, Europe, and Asia. This golden colored spherical fruit, also known as goldenberry, is commercially produced in Ecuador, South Africa, Kenya, Zimbabwe, Australia, New Zealand, Hawaii, India, Malaysia, Colombia, and China. Currently, the production of physalis has expanded to tropical and subtropical countries such as the Caribbean and Colombia, the major producer (NOVOA et al., 2006). In Brazil, physalis is popular in the Northern and Northeastern regions, but it is novelty in the Southern and Southeastern regions. It can be found in local markets mainly in São Paulo and Rio de Janeiro, but it has still been imported from Colombia at high prices since the Brazilian production is still small.

In most countries, the goldenberry is cultivated in backyards for direct consuming. However, they do carry prestige in some international markets, such Europe, where premium prices are paid for the fruits. Besides having a future potential as fresh fruit, it can be enjoyed as an ingredient in salads, cooked dishes, desserts, jams, natural snacks, and fruit preserves (RAMADAN; MÖRSEL, 2003). Moreover, $P$. peruviana is a medicinal plant widely used in folk medicine as anticancer, antimycobacterial, antipyretic, and immunomodulatory and also for treating diseases such as malaria, asthma, hepatitis, dermatitis, and rheumatism (WU et al., 2005).

Despite its importance, there are only few works in the literature concerning this fruit and no study has been carried out in Brazil regarding its chemical composition. Thus, the aim of this work was to determine the centesimal and mineral composition of Physalis peruviana, as well as to evaluate the fatty acid composition of its lipid fraction.

Department of Food Science and Technology, Center of Agricultural Science, Federal University of Santa Catarina, Rod. Admar Gonzaga, 1346, Itacorubi, Florianópolis, Santa Catarina, CEP 88034-001, Brazil, E-mail: ismael.rockenbach@gmail.com

2 Department of Chemistry, Center of Physics and Maths Sciences, Federal University of Santa Catarina, Trindade, Florianópolis, Santa Catarina, CEP 88040-900, Brazil

${ }^{*}$ A quem a correspondência deve ser enviada 


\section{Materials and methods}

\subsection{Materials}

Fruits of Physalis peruviana L., harvested in 2005/2006, were supplied by Italbraz ${ }^{\circledast}$ from Rio Grande do Sul State, located at 28:0:44 $\mathrm{S}$ and 50:56:02 W. The samples were transported to the laboratory at $-5^{\circ} \mathrm{C}$, grinded in a grinder (IKA A 11 Basic) and submitted to thermal treatment at $80^{\circ} \mathrm{C}$ for 10 minutes in order to inactivate enzymes (VALDERRAMA; MARANGONI; CLEMENTE, 2001).

\subsection{Methods}

\section{Centesimal composition}

Moisture, ashes, proteins $(\mathrm{N} \times 6.25)$, and total lipids were determined according to AOAC (2002). The total carbohydrate content was determined by the difference between 100 and the sum of moisture, proteins, total lipids, and ash percentages. The energy value was calculated from protein, total lipids, and total carbohydrates contents using the Atwater system (MERRILL; WATT, 1973).

\section{Mineral composition}

Sample preparation

Physalis peruviana L. samples were digested in $\mathrm{HNO}_{3}: \mathrm{H}_{2} \mathrm{O}_{2}$ (3:1) in a microwave oven with PTFE (Polytetrafluoroethylene) hermetical vessels. After decomposition, the solution was transferred to a $25 \mathrm{~mL}$ volumetric flask. The analyses were carried out at the Laboratory of Atomic and Mass Spectrometry at the Chemistry Department of Federal University of Santa Catarina.

Determination of $\mathrm{Mg}, \mathrm{Zn}, \mathrm{Cu}, \mathrm{Fe}$ and $\mathrm{Mn}$

Magnesium, Zinc, Copper, Iron, and Manganese were determined using an Inductively Coupled Plasma Mass Spectrometer (Perkin-Elmer SCIEX model Elan 6000) (Thornhill, Toronto, Canada). Argon presented 99,996\% of purity (White Martins, São Paulo, SP, Brazil). Rhodium (5 ppb) was used as the internal standard.

\section{Determination of $\mathrm{Na}$ and $\mathrm{K}$}

Sodium and potassium were determined using an atomic absorption spectrophotometer (Analyst 100, Perkin-Elmer, Norwalk, CT, USA).

Determination of $\mathrm{Ca}$

Calcium was determined using an atomic absorption spectrophotometer (Z 8230, Hitachi, Japan).

\section{Fatty acids composition}

Lipid fraction, obtained according to Folch, Lees and Sloanne Stanley (1957), was esterified according to Hartman and Lago (1973). The analyses were carried out in a Gas Chromatographer (17 A Shimadzu/Class GC 10) equipped with a melted silica capillary column SP-2560 (length: $100 \mathrm{~m}$; ID: $0.25 \mathrm{~mm}$ ). Oven temperature programming was $140{ }^{\circ} \mathrm{C}$ isothermal for 5 minutes, increased $4{ }^{\circ} \mathrm{C} \cdot \mathrm{min}^{-1}$ to $240{ }^{\circ} \mathrm{C}$, and held for 20 minutes. The vaporization and detector temperatures were set at 250 and $260^{\circ} \mathrm{C}$, respectively. The carrier gas (Helium) was kept at constant flow-rate of $1 \mathrm{~mL} \cdot \mathrm{min}^{-1}$.

\section{Statistical analysis}

All analyses were carried out in triplicate and the results are presented as means \pm standard deviation (SD).

\section{Results and discussion}

\subsection{Centesimal composition}

Table 1 shows the centesimal composition of Physalis peruviana (physalis), as well as data of some fruits commonly consumed in Brazil.

It was observed that physalis showed a high total lipid content. This is in agreement with Ramadan and Mörsel (2003), who found a total lipid content of $2 \%$ when evaluating Physalis peruviana produced in Germany.

Table 1. Centesimal composition of Physalis peruviana L. and some fruits commonly consumed in Brazil ${ }^{1}$ expressed in g. $100 \mathrm{~g}^{-1}$ in dry weight.

\begin{tabular}{|c|c|c|c|c|c|c|}
\hline Parameter & $\begin{array}{c}\text { Physalis } \\
\text { peruviana L.* }\end{array}$ & $\begin{array}{l}\text { Papaya var. Formosa } \\
\text { (Carica papaya L.) }\end{array}$ & $\begin{array}{c}\text { Apple } \\
\text { (Malus domestica) }\end{array}$ & $\begin{array}{l}\text { Orange var. } \\
\text { Valência (Citrus } \\
\text { sinensis L.) }\end{array}$ & $\begin{array}{c}\text { Strawberry } \\
\text { (Fragaria vesca L.) }\end{array}$ & $\begin{array}{c}\text { Acerola } \\
(\text { Malpighia glabra L.) }\end{array}$ \\
\hline Moisture & $80.97 \pm 1.65$ & 86.90 & 82.60 & 86.90 & 91.50 & 90.50 \\
\hline Proteins & $1.85 \pm 0.31$ & 0.80 & 0.20 & 0.80 & 0.90 & 0.90 \\
\hline $\begin{array}{l}\text { Total } \\
\text { Carbohydrates }\end{array}$ & 13.22 & 11.60 & 16.60 & 11.70 & 6.80 & 8.00 \\
\hline $\begin{array}{l}\text { Energy value } \\
\text { (kcal ou kJ) }\end{array}$ & $88.72 \mathrm{kcal} / 372.62 \mathrm{~kJ}$ & $45 \mathrm{kcal} / 190 \mathrm{~kJ}$ & $63 \mathrm{kcal} / 262 \mathrm{~kJ}$ & $46 \mathrm{kcal} / 193 \mathrm{~kJ}$ & $30 \mathrm{kcal} / 126 \mathrm{~kJ}$ & $33 \mathrm{kcal} / 140 \mathrm{~kJ}$ \\
\hline
\end{tabular}

\footnotetext{
${ }^{\star}$ Data are expressed as mean $\pm S D, n=3$, except for carbohydrates. ${ }^{1}$ Table of food composition (TACO, 2006).
} 
Mineral evaluation, obtained as Ashes, demonstrates that this fruit is also rich in minerals. This fact justifies the qualitative and quantitative analysis of these minerals.

\subsection{Mineral composition}

Minerals play several important roles in human physiology and biochemistry as co-factors for enzymes, and are related to energetic efficiency, fertility, mental stability, and immunity (MAYER, 1997). Table 2 presents data concerning the mineral composition of Physalis peruviana L. and some fruits commonly consumed in Brazil.

The iron content observed in Physalis was of $1.47 \mathrm{mg}^{1} 100 \mathrm{~g}^{-1}$, 5 to 15 times higher to the other fruits presented. This content is higher than that found in traditional sources such as beans (0.8 mg.100 $\mathrm{g}^{-1}$ ) and quantitatively similar to animal sources such as beef (1.8 mg.100 g $\mathrm{g}^{-1}$ ) (TACO, 2006). Among the nutrients available in nature, iron has the major and more complete historical description being a key-element in the metabolism of almost all organisms. In humans, iron is essential for hundreds of enzymes and proteins (BEARD; DAWSON, 1997; FAIRBANKS, 1999).

Like iron, magnesium was found in high quantities in physalis being 2 times higher than in papaya, which is the fruit with the highest magnesium concentration presented in Table 2. This element plays important structural roles in the human body. The adult human organism contains about $25 \mathrm{~g}$ of magnesium: more than $60 \%$ is found in the skeleton, around $27 \%$ is found in the muscles, 6 to $7 \%$ in other cells, and less than $1 \%$ is found outside of cells (SHILS, 1997).

Another essential element, zinc, was also found in high concentrations. However, when comparing to the principal sources such as oysters, shrimp, beef, poultry, fish, wheat germen, and beans the content of physalis is lower (COZZOLINO, 2005). Concerning the calcium content, physalis presented low concentrations, higher than apples only. The potassium content was of $347.00 \mathrm{mg} .100 \mathrm{~g}^{-1}$, higher than the fruits in Table 2. It is important to consider that the normal functioning of human organism depends on the close regulation of potassium concentration inside and outside of the cells (PETERSON, 1997).

The sodium content of $1.1 \mathrm{mg} .100 \mathrm{~g}^{-1}$ was close to that found in apple $\left(1 \mathrm{mg} .100 \mathrm{~g}^{-1}\right)$ and orange $\left(1 \mathrm{mg} .100 \mathrm{~g}^{-1}\right)$ but lower than that found in papaya $\left(3 \mathrm{mg} .100 \mathrm{~g}^{-1}\right)$. As shown in Table 2, the copper content in physalis is much higher than that found in apple, orange, strawberry, and acerola, but lower than that presented in papaya. The importance of copper is due to its ability of donating and receiving electrons, which explains its main function in redox processes and in capturing free radicals in human and animal organisms (LINDER; HAZEGH-AZAM, 1996).

Manganese, an essential element in the bone development and in the metabolism of amino acids, carbohydrates, and cholesterol (COZZOLINO, 2005) was found in relatively high quantities in physalis $\left(0.26 \mathrm{mg} .100 \mathrm{~g}^{-1}\right)$. Other fruits shown in Table 2 and used for comparison presented values lower than that, except for the strawberry $\left(0.33 \mathrm{mg} .100 \mathrm{~g}^{-1}\right)$.

\subsection{Fatty Acids composition}

Physalis can be stored in dry atmosphere for several months and used for oil production once its fatty acids composition is very significant (RAMADAN; MÖRSEL, 2003). Table 3 shows the fatty acid composition of the lipidic fraction of Physalis peruviana L.

Physalis fatty acid profile presented higher concentration of linoleic acid $(72.42 \%)$ in the lipidic fraction. The linoleic acid-rich diets prevent cardiovascular diseases, atherosclerosis, and hypertension. Ramadan and Mörsel (2003) found a linoleic acid content of $70.5 \%$ in Physalis peruviana and an oleic acid content of about $13 \%$, similar to the value found in the present study $(10.03 \%)$.

Table 2. Mineral composition of Physalis peruviana L. and some fruits commonly consumed in Brazil ${ }^{1}$ expressed in $\mathrm{g} 100 \mathrm{~g}^{-1}$ in dry weight.

\begin{tabular}{|c|c|c|c|c|c|c|}
\hline Minerals & $\begin{array}{c}\text { Physalis } \\
\text { peruviana L.* }\end{array}$ & $\begin{array}{c}\text { Papaya var. Formosa } \\
\text { (Carica papaya L.) }\end{array}$ & $\begin{array}{c}\text { Apple } \\
\text { (Malus domestica) }\end{array}$ & $\begin{array}{c}\text { Orange var. Valência } \\
\text { (Citrus sinensis L.) }\end{array}$ & $\begin{array}{c}\text { Strawberry } \\
\text { (Fragaria vesca L.) }\end{array}$ & $\begin{array}{c}\text { Acerola } \\
\text { (Malpighia glabra L.) }\end{array}$ \\
\hline $\mathrm{Fe}$ & $1.47 \pm 0.18$ & 0.2 & 0.1 & 0.1 & 0.3 & 0.2 \\
\hline $\mathrm{Mg}$ & $34.70 \pm 1.50$ & 17 & 5 & 14 & 10 & 13 \\
\hline $\mathrm{Ca}$ & $9.00 \pm 1.00$ & 25 & 3 & 34 & 11 & 13 \\
\hline K & $347.00 \pm 2.50$ & 222 & 117 & 158 & 184 & 165 \\
\hline $\mathrm{Mn}$ & $0.26 \pm 0.02$ & 0.040 & 0.01 & 0.06 & 0.33 & 0.07 \\
\hline $\mathrm{Al}$ & $0.33 \pm 0.01$ & - & - & - & - & - \\
\hline $\mathrm{Ba}$ & $0.06 \pm 0.00$ & - & - & - & - & - \\
\hline Co & $0.01 \pm 0.00$ & - & - & - & - & - \\
\hline $\mathrm{Cr}$ & $0.01 \pm 0.00$ & - & - & - & - & - \\
\hline
\end{tabular}

${ }^{\star}$ Data are expressed as mean \pm SD, $n=3$, except for carbohydrates. ${ }^{1}$ Table of Food Composition (TACO, 2006). 
Table 3. Fatty acids profile (\% w/w) for Physalis peruviana L.

\begin{tabular}{lr}
\hline \multicolumn{1}{c}{ Fatty acids } & $\%$ \\
\hline C16:0 (Palmitic) & 9,38 \\
C16:1 (Palmitoleic) & 0,71 \\
C18:0 (Stearic) & 2,67 \\
C18:1 (Oleic) & 10,03 \\
C18:2 (Linoleic) & 72,42 \\
C18:3 (a-Linolenic) & 0,32 \\
C20:0 (Arachidic) & 1,36 \\
C22:0 (Behenic) & 0,26 \\
C24:0 (Lignoceric) & 0,24 \\
Saturated & 12,87 \\
Monounsaturated & 10,71 \\
Polyunsaturated & 73,78 \\
\hline
\end{tabular}

Saturated fatty acids represented $12.87 \%$ of total fatty acids, with the palmitic acid as the main acid. Ramadan and Mörsel (2003), evaluating Physalis peruviana cultivated in Germany, found a palmitic acid content of $8.62 \%$. These authors also found a stearic acid content of $2.57 \%$, also similar to the value found in the present work (2.67\%).

\section{Conclusions}

The exotic fruit physalis peruviana grown in Brazil presented predominance of linoleic acid in the composition of the lipidic fraction. It also presents high concentration of iron and significant content of several minerals such as magnesium and zinc, essential to human metabolism.

\section{Acknowledgements}

The authors are grateful for the financial support provided by the National Council for Scientific and Technological Development $(\mathrm{CNPq}$ - Conselho Nacional de Desenvolvimento Científico e Tecnológico) and to Italbraz ${ }^{\circledR}$ that gently supplied the Physalis peruviana L. samples.

\section{References}

Association of Official analytical Chemists - AOAC. Official methods of analysis. Washington, D.C., 2002.

BEARD, J. L.; DAWSON, H. D. Iron. In: O’DELL, B. L.; SUNDE, R. A. Handbook of nutritionally essential minerals. New York: Marcel Dekker, 1997.

COZZOLINO, S. M. F. Biodisponibilidade de nutrientes. São Paulo: Manole, 2005.
FAIRBANKS, V. F. Iron in Medicine and Nutrition. In: SHILS, M. et al. Modern Nutrition in Health and Disease. 9 ed. Baltimore: Williams \& Wilkins, 1999.

FOLCH, J.; LEES, M.; SLOANNE STANLEY, G. H. A simple method for the isolation and purification of total lipide from animal tissues. Journal of Biological Chemistry, v. 226, p. 497-509, 1957.

GRANADA, G. G.; ZAMBIAZI, R. C.; MENDONÇA, C. R. B. Abacaxi: produção, mercado e subprodutos. Boletim do Centro de Pesquisa de Processamento de Alimentos, v. 22, n. 2, p. 405-422, 2004.

HARTMAN, L.; LAGO, R. C. A. Rapid preparation of fatty acid methyl esters from lipids. Laboratory Practice, v. 22, n. 8, p. 175-176, 1973.

LAGO, E. S.; GOMES, E.; SILVA, R. Produção de geléia de jambolão (Syzygium cumini Lamarck): processamento, parâmetros físicoquímicos e avaliação sensorial. Ciência e Tecnologia de Alimentos, v. 26, n. 4 , p. $847-852,2006$.

LINDER, M. C.; HAZEGH-AZAM, M. Copper biochemistry and molecular biology. American Journal of Clinical Nutrition, v. 63, n. 5, p. 797-811, 1996.

MAYER, A. M. Historical changes in the mineral content of fruits and vegetables. British Food Journal, v. 99, p. 207-211, 1997.

MERRILL, A. L.; WATT, B. K. Energy Value of Foods: Basis and Derivation, Revised. United States: U. S. Department of Agriculture, 1973. Agriculture Handbook 74. Available from://http:www.nal. usda.gov/fnic/foodcomp/Data/Classics/index.html. Access in: October $15^{\text {th }} 2007$.

NOVOA, R. H. et al. La madurez del fruto y el secado del cáliz influyen en el comportamiento poscosecha de la uchuva (Physalis peruviana L.) almacenada a $12^{\circ} \mathrm{C}^{\star}$. Agronomía Colombiana, v. 24 , n. 1, p. 77-86, 2006.

PETERSON, L. N. Potassium in nutrition. In: O'DELL, B. L.; SUNDE, R. A. Handbook of nutritionally essential minerals. New York: Marcel Dekker, 1997.

RAMADAN, M.F.; MÖRSEL, J.T. OilGoldenberry (Phisalisperuviana L.). Journal of Agricultural and Food Chemistry, v. 51, p. 969-974, 2003.

SHILS, M. E. Magnesium. In: O'DELL, B. L.; SUNDE, R. A. Handbook of nutritionally essential minerals. New York: Marcel Dekker, 1997.

TACO - Tabela brasileira de composição de alimentos. T113 Versão II. 2 ed. Campinas: NEPA-UNICAMP, 2006.

VALDERRAMA, P; MARANGONI, F.; CLEMENTE, E. Efeito do tratamento térmico sobre a atividade de peroxidase (POD) e polifenoloxidase (PPO) em maçã (Mallus comunis). Ciência e Tecnologia de Alimentos, v. 21, n. 3, p. 321-325, 2001.

WU, S. J. et al. Antioxidant activities of Physalis peruviana. Biological \& Pharmaceutical Bulletin, v. 28, n. 6, p. 963-966, 2005. 